\title{
Capital punishment and the medical profession
}

In the UK, capital punishment has been abolished - except for treason; and in the Isle of Man, where it has not been used for many years. From time to time, there are calls for its return. Recent miscarriages of justice-particularly those concerned with terrorist bombings - have underlined the real risks of executions of innocent persons - as happened to Timothy Evans. These events may, at least for the moment, reduce any pressure for the return of capital punishment in the UK, but pressure to restore it will certainly recur from time to time. Meanwhile, it continues to be practised in over 100 countries. There have been, for instance, over 180 executions in the United States since 1976.

This memorandum reviews some of the many ethical dilemmas confronting doctors, which arise from the practice of capital punishment.

\section{Medical participation in capital punishment}

This subject has been reviewed recently by Amnesty International (1989), the World Psychiatric Association (1989), the British Medial Association (1992) and the Royal College of Psychiatrists (1992). Leading articles have been published in the British Medical Journal (Bonnie, 1992) and in The Lancet (1993).

\section{Legal proceedings before and during trials}

The Royal College of Psychiatrists has said "It is essential that the law and citizens in conflict with the law are provided with highly qualified, well trained and ethically sophisticated psychiatrists. most of whom will be working in the field of forensic psychiatry".

When capital punishment is involved, there are many dilemmas in the stages prior to sentencing. especially for psychiatrists, who are often involved in judgements about the sanity and responsibility of the accused. Bonnie, a US lawyer, maintains that "Capital prosecutions do not differ in respect from other criminal cases. (It would surely be difficult to sustain the argument that medical testimony that might lead a judge to impose a death sentence violates medical ethics even though testimony that might lead the court to impose long term, and often debilitating, imprisonment does not)". A US psychiatrist puts a contrary view, as follows. "The employment of psychiatrists in trials at law has gone far beyond what society expects from any other type of expert witness. This is manifest primarily in trials where the death penalty is involved. Here we find the anomaly of a physician sworn to devote himself to the preservation of human life, dealing out opinions whereby the survival or destruction of another human being hinges on the turn of a word. Many psychiatrists refuse any longer to serve as expert witness in capital cases" L. J. West, quoted in Medicine Betrayed pp. 104-105 (British Medical Association, 1992). It is certainly true that many psychiatrists are reluctant to get involved in the United States, as is the fact that the gap may be filled by psychiatrists who are less expert - notably in the US by Dr James Grigson ("Dr Death") whose activities have been widely reported and criticised, to no effect (Medicine Betrayed, pp. 106-107).

\section{Post-sentencing}

Therapy. While prisoners require and must have appropriate treatment, problems arise in the treatment of prisoners who may be declared incompetent for execution because of a deterioration in their mental or physical state and, correspondingly, competent for execution if they receive treatment. A related problem is the refusal of a prisoner to take medication which is maintaining his mental state, with the aim of precipitating a deterioration. The Royal College of Psychiatrists has recommended that involuntary care should only be given to a prisoner if the psychiatrist has obtained a legal guarantee that the prisoner has had his or her sentence commuted. The BMA has given guidelines that no doctor should ever give medical evidence for "fitness for punishment" of whatever degree of severity. This rule applies most strongly to "fitness for execution".

The execution process. In the execution process itself, doctors may be involved in supervising and/or administering lethal injections, advising on the drugs to be used, certifying death and, if the prisoner is deemed still alive, advising on further lethal procedures. The conflicts for doctors are very clear in the USA. 
The state of Oklahoma, when reintroducing capital punishment in 1978 , legislated that "The chief medical officer of the penitentiary, or the medical director of the Department of Corrections, or a physician designated by the warden, must be present at the execution; and after the catheter has been inserted the examining physician shall inspect the catheter and monitoring equipment and determine that the fluid will flow into the vein" (Medicine Betrayed, p 112).

On the other hand, the American Medical Association (and the World Medical Association) permit only the certification of death by a doctor, who should not take any more active role in the execution. Because of increasing reports of physician involvement in lethal injections, the AMA adopted a strong resolution in 1990 "reaffirming, clarifying and publicising its position that it is unethical for physicians, regardless of their personal views on capital punishment, to participate in legally authorised execution, except to determine or certify death". The Association also informed medical licensure boards and certification agencies that physician participation in supervising or administering lethal injection is a serious violation of the ethical standards of the medical profession.

Certifying death. Because certifying death implies that the prisoner may not be dead and thus require further lethal procedures, the BMA working party recommended the "ending of the role of the doctor as the one person in the execution chamber who tells the executioner where or not to continue". They recommended that medical certification of death should be done only after an official has confirmed that the prisoner is dead and certification should take place outside the execution chamber and well after execution has taken place.

\section{Conclusion}

The Royal College of Psychiatrists resolved "to draw attention to the diverse effects on the medical profession of there being a death penalty. In relation to psychiatry, this is likely to lead to a withdrawal from the field of some of the most skilled practitioners, with damaging consequences for those persons who require assessment under the appropriate legal system".

Professor Bonnie, a leading US lawyer, concludes "administration of the death penalty in the modern era spawns one distressing paradox after another. Lawyers, judges, doctors, and anyone else who participates in the process inevitably becomes mired in ethical quicksand. Unfortunately, professional efforts to evade the quicksand tend to erode the rights and interests of defendants in capital cases and condemned prisoners. The death penalty should be abolished, but as long as it remains in force the dignity of the condemned should not be subordinated to the dignity of the medical profession".

The Lancet, in a recent leader, concluded that "professional, medical (and nursing) organisations should be persuaded that the death penalty, which breaches the Universal Declaration of Human Rights in two places, no longer has any part in a civilised society. The non-involvement of doctors should be total, and professional guidelines should say so. As for torture, so for capital punishment, and medical organisations should leave no room for ambiguity".

The continued abolition or the restoration of capital punishment is a matter to be decided by Members of Parliament. They are asked to bear in mind the ethical problems which capital punishment presents to the medical profession.

\section{References}

AMnEsty InTERnational (1989) Health Professionals and the Death Penalty.

BonNIE R.J. (1992) The death penalty - when doctors must say no. British Medical Journal, 305, 381-382.

BRTtish MEdical Association (1992) Medicine Betrayed. The Participation of Doctors in Human Rights Abuses. Report of a Working Party. BMA: Zed Books.

ROYAL COLLEGE OF PSYCHIATRISTS (1992) Resolution concerning the participation of psychiatrists in executions. Psychiatric Bulletin, 16, 457.

THE LANCET (1993) Doctors and death row (editorial). The Lancet. 341, 209-210.

WORLD PSYChIATRIC ASSOCLATION (1989) Declaration on the Participation of Psychiatrists in the Death Penalty.

Special Committee on Unethical Psychiatric Practices

February 1993

Approved by Council June 1993

(It is proposed to recommend to the Conference of Medical Royal Colleges that this may be used as a briefing statement for members of Parliament). 